type $\alpha$ parents expunge type $\beta$, and that type $\beta$ wins over type $\gamma$, it follows that type $\alpha$ will win over type $\gamma$ (refs 1,4$)$.

Mitochondria in Physarum are however not always inherited uniparentally. Kawano et $a .^{2}$ show that the above is all true if the mitochondria from both parents lack a particular plasmid. But if one of the mitochondrial sets has the plasmid (the mif $^{+}$condition), whereas the other does not (mif ${ }^{-}$), then the mitochondria fuse, undergo recombination and subsequently divide within the zygote. Most or all of the derived mitochondria inherit the plasmid in an unaltered form. When two mif ${ }^{-}$gametes mate mitochondrial fusion is not witnessed, indicating that organelle fusion is a direct consequence of the possession of the plasmid. The consequences of fusion between two if $^{+}$gametes is unknown. As Kawano et al. comment, the behaviour of mitochondria in $\mathrm{mif}^{+} / \mathrm{mif}$ matings appears to constitute some sort of mitochondrial meiotic cycle.

More significantly, a system such as this is very similar to that proposed by Hickey and Rose ${ }^{9}$ for the initial stage in the evolution of sex. Attempting to understand the origins of both the transfer of genes from one individual to another and of the fusion of gametes, Hickey and Rose proposed that a parasitic gene might underlie the process. Consider a transposon or similar selfish gene in a cell. If this gene is incapable of horizontal transmission, it is stuck in the vertical lineage of its host cell. But what if this gene can force its cell to fuse with another, leave a copy of itself in this cell, and then force the two cells to split apart? The gene would receive a twofold transmission advantage while enduring little cost. Hence we might expect such a gene to spread. Kawano et al.'s observation of the mitochondrial plasmid in Physarum is direct support for the possibility that selfish genes are capable of manipulating their hosts in the manner Hickey and Rose propose.

Recombination between mitochondrial genomes has also been found in a few other organisms, the best studied of which is yeast ${ }^{10}$. Recombination can involve biased gene conversion, or a similar process at the $\omega$ locus such that in a cross between cells which are $\omega+$ and $\omega$ - nearly all of the mitochondria end up being $\omega+$ (ref. 10). Unlike the Physarum case, $\omega+$ is not a plasmid but an intron ${ }^{10}$. No biased conversion is seen in crossing of cells with like-type mitochondria. But it is not known if $\omega+$ can induce mitochondrial fusion. Recombination is known between mitochondria in the absence of $\omega+$. The most commonly cited case in support of Hickey and Rose is that of the F plasmid of the bacteria Escherichia coli which is responsible for the production of a repro- ductive pilus through which a copy of the plasmid can migrate from one cell to another ${ }^{11}$. In this system, fusion of bacteria is not seen and the recombination is found only in the recipient bacterium.

Could a selfish genetic element be responsible for fusion between eukaryotic cells? Once again, evidence comes from Physarum. One of three consequences ensue when two plasmodia meet ${ }^{12}$. If they are genetically identical at at least four particular loci, then the two plasmodia fuse; this fusion is a vegetative process not involving nuclear fusion. If the plasmodia differ genetically then either no fusion occurs, or fusion ensues followed by a post-fusion incompatibility reaction. This reaction involves the nuclei of the partner bearing a particular recessive allele being condensed, enclosed in vacuoles and eliminated from the cytoplasm. The other nuclei containing the dominant killer gene are unaffected. Hence, as with the $\omega$ locus, the F plasmid, Physarum's mitochondrial plasmid and similar selfish genes, the aggressive dominant gene increases in frequency at least in the plasmodium. The fate of the mitochondria after fusion of the two plasmodia is unknown.

All this is consistent with a Hickeyand-Rose type view of the evolution of fusion. But what of the evolution of recombination? The independent segregation of chromosomes at meiosis follows as a consequence of the fusion of haploid gametic nuclei. Why, in most organisms, do these nuclei not remain as two independent entities as they do in some fungi? The post-fusion incompatibility reaction seen in Physarum also involves the induction of nuclear fusions. Lane and Carlile ${ }^{12}$ suggest that by fusing with a nucleus with the dominant gene, the nuclei with the recessive gene might escape destruction. Could the fusion of haploid nuclei be a result of selection to avoid the deleterious consequences of similar competition between the two genetically different nuclei?

Laurence $D$. Hurst is in the Department of Zoology, University of Oxford, South Parks Road, Oxford OX1 3PS, UK.

1. Meland, S. et al. Curr. Genet. 19, 55-60 (1991)

2. Kawano, S. et al. Protoplasma 160, 167-169 (1991)

3. Kawao, S., Anderson, R. W., Nanba, T. \& Kuroiwa, T. J. gen. Microbiol. 133, 3175-3182 (1987).
(19)

4. Kawano, S. \& Kuroiwa, T. J. gen. Microbiol. 135 1559-1566 (1989)

5. Eberhard, W. G. Q. Rev. Biol. 55, 231-249 (1980)

6. Kuroiwa, T. Microbiol. Sci. 2, 267-270 (1985)

7. Grell, K. G. Protozoology 225 (Springer, Berlin, 1973)

8. Kawano, S., Kuroiwa, T. \& Anderson, R. W. J. gen Microbiol. 133, 2539-2546 (1987)

9. Hickey, D. H. \& Rose, M. R. in The Evolution of Sex (eds Michod, R. E. \& Levin, B. R.) 161-175 (Sinauer Sunderland, Massachusetts, 1988)

10. Dujon. B. in The Molecular Biology of the Yeast Saccharomyces Vol. 1 (eds Strathern, J. N., Jones, E. W. \& Broach, J. R.) 505-635 (Cold Spring Harbor Laboratory Press, 1981)

11. Willets, N. S. \& Skurray, R. A. Rev. Genet. 14, 14-76 (1980)

12. Lane, E. B. \& Carlile, M. J. Cell Sci. 35, 339-354 (1979).

\section{Arresting waste}

Plastic waste, says Daedalus, is not really immortal. Exposed to air and daylight, it gradually crumbles into small particles which are ultimately metabolized by bacteria. Only when buried in landfill dumps, out of reach of air and daylight, does it last indefinitely.

On this argument, plastic junk should simply be spread out on waste ground, or gathered into heaps, and left to weather. Daedalus now proposes to do just this, usefully. He points out that solvent vapours in the air can attack polymers, softening them and making their surface tacky. When the absorbed solvent evaporates again, the polymers recover their normal strength and character.

So DREADCO engineers are compacting domestic and commercial plastic waste into a sort of open-weave bonded structural material. The mass of detergent bottles, yogurt pots, plastic crockery and cutlery, and so on, are exposed to solvent-loaded air while passing between slightly compacting rollers. The items soften and stick together, and emerge from the drying chamber as an open but continuous material whose individual components, deformed and firmly adhering, are still discernible. The solvent vapour can be recovered for re-use. The waste need not be segregated into different polymers, or even freed completely from other waste. A few tin cans or cardboard boxes glued into the structure would not matter.

Some outdoor use has to be found for 'Wastebloc' ${ }^{\circledR}$ while it slowly breaks down. Daedalus proposes to use it as a central crash barrier for motorways. A vehicle ploughing into it would rapidly be slowed by the bending and shearing of thousands of plastic components, but would suffer little damage in return. In this way, the vast motorway network will usefully double as a waste tip. Wastebloc barriers, endless miles of deformed plastic refuse welded together into a thick monolithic fence, will of course be irredeemably ugly, thus harmonizing pleasantly with the motorway ambience. Plants and shrubs could usefully be encouraged to grow round and through the Wastebloc fencing. The resulting 'reinforced hedge' would be even more energy-absorbing; and Wastebloc will probably break down and biodegrade faster in the rich micro-ecology of a plant community. As fast as it weathers away, or is damaged by traffic, new plastic waste will be grafted onto it by special rubbish trucks fitted with compacting rollers and vapour-dispensing equipment. Thus plastic rubbish, the bane of modern waste disposal, will enjoy a long and useful retirement while nature slowly reclaims it.

David Jones 